\title{
Yiddish Radicalism, Jewish Religion: Controversies in the Fraye Arbeter Shtime, 1937-1945
}

Lilian Türk \& Jesse Cohn ${ }^{+}$

* Hamburg University

+ Purdue University Northwest

"Anarchism" and "religion" are categories of belonging that serve as tools for identification - both of oneself and of others. Yiddish-speaking anarchism is overwhelmingly remembered as an antireligious movement, a characterization drawn from its early experiences in the immigrant communities of the U.S. (circa I880-1919). However, this obscures the presence of competing definitions of both religion and anarchism within the Jewish anarchist milieu and fails to take into account the social character of processes of identification unfolding over time. A generation after its circulation peaked, in a context of declining Jewish anarchist "groupness" (1937-1945), the Yiddish anarchist newspaper Fraye Arbeter Shtime hosted debates over religion which reveal a far broader spectrum of interpretations than were apparent in the earlier period. Examining these debates demonstrates the subversive fluidity more than the rigidly bounded character of anarchist and religious identities alike, as an emergent consensus among Jewish anarchists names domination rather than religion per se as the common enemy.

The historians refuse to confront Jewish radicalism in its own right, even as they make shrewd remarks about its unanticipated role; the Jewish radicals, in similar fashion, refused to confront religion in its own right, even as they made shrewd remarks about its unacknowledged uses.

(Howe 1976: 323)

How to cite this book chapter:

Türk, L. and Cohn, J. 20I8. Yiddish Radicalism, Jewish Religion: Controversies in the Fraye Arbeter Shtime, I937-I945. In: Christoyannopoulos, A. and Adams, M. S. (eds.) Essays in Anarchism and Religion: Volume II. Pp. 20-57. Stockholm: Stockholm University Press. DOI: https://doi. org/Io.I6993/bas.b. License: CC-BY. 
Once we are liberated from the vulgar, theological model of history that has been endlessly and scrupulously repeated by modernity, we should no longer be surprised or horrified by the "return" of religion [within anarchism]. Religion "returns," but - like all other things - it returns in an infinite, unpredictable series of events and situations [...]. Religion "returns" at once the same and yet different and surprising.

(Colson 2007: 60)

Those familiar with the history of Jewish radicalism in America may have heard of the Yonkiper beler (Yom Kippur Balls), antireligious festivities held on the Day of Atonement between I 889 and I903 by young anarchists such as the illustrious Emma Goldman and Alexander Berkman, featuring outrageous mockeries of ritual piety. ${ }^{\mathrm{I}}$ Indeed, the rejection of religion has a prominent place in the history of Jewish anarchist ideas. The assumptions that society is constructed according to an arbitrary divine plan not alterable by human intervention, that rules established by the will of God are the foundation of a system of law not accessible to reason but merely to be accepted by submissive believers - these were denounced in the strong critiques of religion issuing from Johann Most and Mikhail Bakunin. ${ }^{2}$ Religion was

I On these occasions, four-page leaflets (tfile-zakes) were disseminated, filled with parodies and satire, lampoons of prayer and religion in general and Judaism in particular (N. Goldberg in Tsherikover I945: 434). Johann Most, Emma Goldman (I869-1940) and Alexander Berkman (1870-I936) gave speeches at Yonkiper beler alongside Saul Yanovsky (a.k.a. Shoel Yanovski, I 864-I939, first editor of the revived Fraye Arbeter Stime [FASh], Di Ovnt Tsaytung and Di Fraye Gezelshaft), Roman Lewis (1865-1918, founder of the Pioneers of Freedom (Pionirn der frayhayt), and Mikhail Zametkin (a.k.a. Michael Zametkin, I8 59-I935, a popular orator and writer for the Arbeter Tsaytung); see Avrich I988: pp. I9I ff. Orthodox and Reform Jews opposed the festivities, which rewrote and mocked Kol nidre (the recitation that introduces Yom Kippur), provided a buffet with alcoholic beverages, at which music was played and danced to and where the Marseillaise "and other hymns against Satan" were sung (N. Goldberg in Tsherikover I945: 440-4, 444; transl. LT; see also Howe 1976: 105-107; Avrich 1973: 38-42; Avrich I988: I76 ff., esp. I 80 f.; Rosenberg 200I).

2 See e.g. Most I 883. Johann Most (I846-I906), next to German socialists, exercised great influence on Jewish anarchists in late $19^{\text {th }}$ century London and US-American cities (N. Goldberg in Tsherikover I945: 426; see also E. 
interpreted as an obsolete, irrational system of ideas that blocked or at least distorted thought. According to the historian Nathan Goldberg, who describes a pervasive antireligious self-understanding among Jewish immigrants until 1900 , this concept of religion was particularly widespread among Jewish anarchists. ${ }^{3}$ Robert G. Ingersoll's Some Mistakes of Moses and its two translations into Yiddish in I 886 and 1903 greatly influenced the militant atheism of the weekly paper Arbeter Fraynt, among others. Far from being limited to Jewish radicals, agnosticism and scepticism were widespread in the East European Jewish Enlightenment (Haskole) and among all those who left the traditional community, defined by a strict interpretation of Judaism perpetuated by authoritarian religious and educational institutions. ${ }^{4}$ It was not unusual to be an agnostic, atheist or "Epicurean" 5 thinker by I 880 , but according to Goldberg, the highly distinctive means employed by Jewish anarchists to agitate against religion turned a great part of the Jewish community away from them. ${ }^{6}$

Tsherikover, Di amolike anarkhistn in gerangl kegn idishn got [The former anarchists in struggle against the Jewish god] in Idisher kemfer, 7.3.I94I.

3 N. Goldberg, in Tsherikover r945: pp. $434 \mathrm{ff}$.

4 The critique of the traditional educational system (kheyder), teachers and authoritarian educationalists (melamdim) and the municipality of the shtetl (small town), derived from the East European Jewish Enlightenment (Haskole), was a widespread topos among socialist Jews by the time of the I905 Russian Revolution, as reflected in numerous autobiographies (e.g. I. I. Singer I946). Many biographies of Haskole document a progress set in motion by newspapers and industrialization, leading to a reform of education; representatives of the Jewish Enlightenment (maskilim) like Yoysef Perl (I773-I 839), Avrom Gottlober (I 8IO-I 899) or his student Avrom Goldfaden (I840-I908) were teachers. This process and the tremendous importance of newspapers for education in the shtetl were both humorously and melancholically described by Sholem Aleichem (Solomon N. Rabinovich, I859-I916) in Drayfus in Kasrilevke (I902).

5 References to Epicurus often served to represent Jewish anarchists' self-perceptions, perhaps evoking associations with a search for the origin and meaning of human understanding and reason, a strong emphasis on the atomistic nature of science, and the struggle against fate and predetermination. These fundamental themes were reflected in the debate in FASh, as we will see.

${ }^{6}$ N. Goldberg, in Tsherikover I945: 4I8. 
Consequently, the identification of anarchism and radicalism in general ${ }^{7}$ as antireligious was widespread among participants in the movement, and this identification is echoed by the secondary literature - a testament to the effectiveness of Jewish anarchists' antireligious activism. ${ }^{8}$ Religion and anarchism are very broad categories of identification - categories used by activists and taken over by researchers when interpreting historical sources. However, as Paul-François Tremlett notes, contemporary social science has increasingly called into question the very boundaries of "religion" as a category of analysis, and indeed, we can discern competing interpretations of that category within anarchist discourse. ${ }^{9}$ We would suggest distinguishing between self-defined groups and the abstract categories applied by outsiders in order to avoid the false assumptions and dichotomies that are created when Jewish and gentile anarchisms are characterised as antireligious movements tout court. It is worth considering, for instance, that Bakunin, famous for his I 87 I masterpiece God and the State (translated into Yiddish by Shoel Yanovski in I90I), argued strongly against "official" religion intertwined with state power, but advocated a more nuanced view on decentralised denominations and their freedom of conscience and propaganda. ${ }^{\text {Io }}$ To translate this into a claim that Bakunin was "pro-religion" would be as short-sighted as characterising him as purely and simply "antireligious".

7 Most actors used the term 'radical' to describe themselves. The term 'anarchist' was used less often; Yiddish anarchist writers instead called themselves frayhaytlekbe sotsyalistn (libertarian socialists) or Epicurean thinkers.

${ }^{8}$ See e.g. W. J. Fishman, who correctly observes that "the radical intelligent eschewed religion as obscurantism maintained by the rigidity of superstitious ritual and rabbis who acted as a brake on anti-Tsarist activity. Jewish tradition was associated with the physical and mental degradation of the ghetto; and Yiddish was despised as the jargon of slaves, while Hebrew was elevated to the proper form of communication between Jews" (Fishman 2004: 98 f.).

9 Tremlett 2004: 367-68.

ro In his "Revolutionary Catechism", Bakunin demanded " $[t]$ he abolition of all state religions and all privileged churches, including those partially maintained or supported by state subsidies", but also "Absolute liberty of every religion to build temples to their gods, and to pay and support their priests" (77). 
Recent studies delving into the Yiddish radical milieu describe a range of nuanced attitudes towards religion. Annie Polland demonstrated the intellectual and social ties between 'radical' and 'religious' readers of the Yiddish socialist daily Forverts at the very beginning of the 2oth century. ${ }^{\mathrm{II}}$ Editors of the paper sought ways to reach a wider audience and it becomes clear that as early as in I900 one cannot assume a clear distinction between a religious and a secular milieu: “The Forverts' debates point to the vigour with which Jewish immigrants and their organizations wrestled with religion. They are especially significant in showing how religion and reactions to it did not disappear with the waning of religious authority, but rather became all the more pressing." I2

When we investigate the categories of religion and anarchism as they appear in discursive practice - i.e., in the context of an open-ended, contentious dialogue between multiple actors - we find that it was domination, not religion per se, that the "antireligious" anarchists opposed, and that it was domination that the "religious" anarchist writers struggled to disavow while justifying their self-location ${ }^{\mathrm{I} 3}$ within the anarchist movement. This can best be demonstrated by examining a debate among Yiddish writers

II Polland 2007. In her study of two debates in the Yiddish socialist daily Forverts, Polland demonstrates the "shared worlds" of 'radical' and 'religious' readers in 1904 and I905. Letters showed similar argumentative strategies, but also social ties at people's work places, in families, marriages and even friendship. See also Michels 2005: I 84. Other research (e.g. Cohn, Biagini) has pointed to themes shared by antireligious Jewish anarchists and the Jewish religious tradition itself (e.g., iconoclasm and messianism), affinities made tangible in the relations between Gustav Landauer and Martin Buber, for example.

${ }^{\mathrm{I} 2}$ Ibid.: 376. Years later, in I9I5, boundaries remained blurred, as "a reporter for the Orthodox Morgn zhurnal, noted the increasing 'tolerance on the Jewish streets,' manifested by both the pious and the radicals. [...] he relayed spotting a 'known anarchist sitting and talking with an orthodox rabbi' in a friendly manner. He also noted how Orthodox study groups hired leaders of the extreme left to deliver speeches of general, not political, interest at their meetings." (ibid.: 39I).

${ }_{3}$ In order to capture some of the phenomena that are usually attributed to the term identity (hypostasized into a falsely concrete "thing"), the sociologist Rogers Brubaker offers process-oriented terms like identification and categorization, as well as self-location and social location, together with terms for qualities, such as commonality, connectedness, and groupness (Brubaker 2004: pp. 28 ff.). 
published in the anarchist weekly Fraye Arbeter Shtime (Free Voice of Labor or FASh) between 1937 and I945. Instead of a single, clearly antireligious point of view, as we shall see, the articles present a heated debate on Yidishkayt ("Jewishness") interpreted in political, ethnic and religious terms, and its relation to different concepts of anarchism. We begin by exploring the themes emerging in the unique contributions of Abba Gordin, then situating these within the equally unique "counterpublic space" that was the FASh. This, in turn, will allow us to see how antireligious and religious anarchist perspectives were articulated in a period when Jews' political engagement with anarchism, while still significant, could no longer take the same form that it had in the era of the Yonkiper beler.

\section{A central figure: Abba Gordin (1887-1964)}

At the heart of this debate was Abba Gordin, a philosopher, social psychologist, biographer, and educationalist whom Paul Avrich describes as one of the most important figures in Russian anarchism. ${ }^{\mathrm{I}}$ Allan Antliff reads Abba and his brother Velfke Gordin, from the perspective of their Russian-Revolution-era writings, as antireligious "arch-materialists", suggesting that their primary inspiration came from Max Stirner's attack on "the metaphysical thinking underpinning religion" as "the foundation for the hierarchical division of society". ${ }^{15}$ However, Antliff notes that their I9 8 Manifest Pananarkhistov (or Pan-Anarchist Manifesto) rather even-handedly denounced " $[\mathrm{t}]$ he rule of heaven and the rule of nature - angels, spirits, devils, molecules, atoms, ether, the laws of God-Heaven and the laws of Nature, forces, the influence of one body on another" as equally arbitrary social constructs: "all this is invented, formed, created by society". ${ }^{16}$ Indeed, for the

${ }^{14}$ Avrich I973: 9. Gordin's works Draysik yor in Lite un Poyln (I958; Thirty Years in Lithuania and Poland) for the period ending in I9I7, In gerangl far frayhayt (1956; In struggle for freedom) for 1917-I919, and Zikbroynes un kheshboynes. Memuarn fun der rusisher revolutsye (1955; Memories and Accounts: Memoirs of the Russian Revolution) for I9I7-I924 are contributions to a history of Bolshevism and the facets of the revolutionary movement in Russia.

I5 Antliff, “Anarchy, Power, and Poststructuralism”, SubStance 36.2 (2007): 6I-62.

I6 Qtd. in Antliff 6I-62. 
Gordins, the materialistic and scientistic pretensions of Marxism were to be denounced as yet another religious illusion:

For them, science - by which they meant all rational systems, natural science and social science alike - constituted the new religion of the middle class. The greatest fraud of all was Marx's theory of dialectical materialism. "Marxism", they declared, "is the new scientific Christianity, designed to conquer the bourgeois world by deceiving the people, the proletariat, just as Christianity deceived the feudal world". Marx and Engels were "the Magi of scientific socialist black-magic". ${ }^{\text {I7 }}$

Nor did Abba Gordin abandon this line of attack on religion and science alike after the collapse of the revolution: in Communism Unmasked, he writes that "The instinctive messianic spark glimmering in the heart of the laborer [. . . d devours his hard-won common sense, his healthy realistic look on life, and he forgets himself and becomes an easy victim of fantasms", and he denounces authoritarian communism precisely by calling it a "quasi-religion". ${ }^{18}$

In these statements, Gordin clearly located himself within the antireligious radical narrative. In other texts, however, we find different shades of pro-religious arguments. Joseph Nedava, a historian and friend of his, writes that this "rebel" and "iconoclast" promoted a revival of what he saw as the core values of Jewish ethics. ${ }^{19}$ God is seen as force of mutuality created by individuals. The concept of deity - conceptualised as a vision of the $I(I k h)-$ was expressed by constant social and cultural evolution. The process towards individualism and eventually to collective "inter-individualism", as Gordin called the future state of society, entailed a synthesis between individuality and mutuality. ${ }^{20}$ But

${ }_{17}$ Avrich, The Russian Anarchists 178.

I8 Gordin I940: 3I, 55.

19 Nedava I974: 74 .

$2 \circ$ A friend of Gordin's, P. Gdalya, published an anthology of anarchist thinkers, suggesting an entire anarchist tradition set in motion and developed by certain philosophers, eventually coming to fruition with Gordin's concept of “inter-individualism” (P. Gdalya I963). The book is a collection of biographies starting with William Godwin, followed by Pierre J. Proudhon, Élisée Reclus, Domela Nieuwenhuis, Johann Most, Errico Malatesta, Jean Grave, Sébastien Faure, Francisco Ferrer y 
religion and the Jewish tradition were not merely a pool from which Gordin took allegories and moral lessons in order to transform them into a revolutionary programme. Religion, he wrote, must be understood in sociological and psychological terms: The religious feeling creates social bonds and changes them. It spans the abyss separating socialism and individualism and creates "inter-individualism." ${ }^{21}$ In this respect religious ideas become real as soon as adherents believe and make them real.

Gordin's concept of God shifts from antireligious and anticlerical barbs hurled against a supreme being to instrumental interpretations of God as the foundation for a higher rationality and ethics to a phenomenological interpretation comparable to Rudolf Otto's notion of a supernatural Sensus Numinis. The religious feeling and striving for justice in Gordin's words can only be felt by a Jewish believer. ${ }^{22}$ Occasionally Gordin draws on esoteric images such as the ingestion of $\operatorname{light}^{23}$ to describe the purification of body and soul as a way of coming closer to deity and to the future state of society. These shifting concepts reveal the difficulty of locating Gordin's ideas in a continuum ranging between Orthodoxy and free thought.

Accordingly, in his writings on religion, Gordin both shares and subverts the modern notion of religion as an entity essentially separate from power and politics. ${ }^{24}$ On one side Judaism is idealized as a non-political entity, with a proud history of a diasporic, self-governed, stateless society. Judaism or rather Jewishness

Guardia, and Abba Gordin. Gordin himself wrote a preface, thanking the aid of Ashuakh, a cooperative publishing house in Tel Aviv.

${ }^{21}$ Gordin I938: I03. In this respect Gordin followed principles of idealism, which argued that ideas formed reality. Ludwig Feuerbach, Bruno Bauer and Max Stirner were heavily attacked as 'German idealists' by Karl Marx in The German Ideology (Die Deutsche Ideologie, I846).

${ }^{22}$ Judaism evokes a prophetic feeling of justice, which can be directed against the depravity of capitalism, militarism and imperialism (Gordin I940: I0). For an approach to Gordin's Yiddish writings by the end of the I930s and the beginning of the I940s, see Türk 20I4, ch. 2.

23 Gordin I938: 291.

${ }^{24}$ See the essays in Fitzgerald 2007 for an investigation into the dichotomy of religion and power as distinct and separate alternatives, as "two essentialized domains, one concerned with power and public order, the other the private inner world of prayer" (ibid.: 2 ). 
(Yidishkayt) must be seen an exception to the general rule, as an ethical entity, to which secular or political institutions are extraneous. ${ }^{25}$ In this respect, Gordin, as an anarchist who despises statist and militarist societies, shares or rather hypostasizes the notion of religion as entity separate from politics. On the other side, the author subverts this notion of religion and its separation from politics and official affairs. He claims that the privatized notion of 'religion' is foreign to Judaism. The synagogue has always been a social and secular ("worldly," veltlekh) institution, next to being the house of prayer it served as club, library, lecture hall, guest house and playground for children. Most parts of the Talmud are worldly jurisprudence connected to holy texts, which are themselves worldly. ${ }^{26}$ Here, as in antireligious lines of argumentation, the ideological and apologetical function of the dichotomy of religion and politics is obvious.

While Nedava and the Israeli historian Moyshe Goncharok give rich descriptions of Gordin's character, a systematic history of his (anti-)political, religious and anarchist thinking is still a task to be fulfilled. ${ }^{27}$ Gordin went through a course of education shared by many Russian-Jewish intellectuals of his time. Along with his brother he attended the traditional primary school, learned Talmud, autodidactically learned Russian, and secretly acquired Russian progressive and revolutionary writings. ${ }^{28}$ After abetting a jailbreak in 1905 , Gordin was arrested but was released shortly thereafter. In September I9II, the first and only issue of an anarchist educationalist paper, Der Yunger Yid [The Young Jew], edited by the brothers Gordin, was published. ${ }^{29}$

25 Gordin I940: 2 I f.

26 Ibid.: $250 \mathrm{f}$.

27 Nedava I974; Goncharok 2002.

${ }_{28}$ Gordin I958: I 2. Zeev (Zalman) "Wolf” Gordin tended to MarxismZionism (Poale Tsion) during the time of the Russian revolution in I9I7. Both brothers were influential among industrial workers and sailors in Russian cities. Wolf Gordin underwent remarkable personal transformations: after leading the St. Petersburg branch of the Anarchist Federation, he turned to the Bolsheviki, then broke away from Lenin after a while, fled to the United States and eventually became a Protestant missionary (Avrich I967: 237; Nedava I974: 75).

29 The paper was subtitled "Monthly newspaper for pedagogy, social life, philosophy, and the spreading of anarchism”. In Vilnius, just as in 
Both authors supported what they called Pan-Anarchism..$^{30}$ Initially, Abba Gordin published political and educational pamphlets in Russian and became a prominent figure in the Moscow Anarchist Federation in I9I6. He visited Nestor Makhno together with Emma Goldman and Alexander Berkman after the civil war in I9I 7. ${ }^{31}$ Makhno seems to have distanced himself from Gordin, characterizing him and other members of the Federation as "men of books rather than deeds" who "seemed mesmerised by their own words and resolutions and devoid of the will to fight for their ideals". ${ }^{32}$ On 6 February 1926, Gordin was forced to flee via Siberia to the United States, where he then published mainly Yiddish works which he had begun in Russia. ${ }^{33}$

\section{A Yiddish anarchist counterpublic space}

The debate in which Gordin played such a central role took place among Yiddish-speaking intellectuals who did not in every case refer to themselves as anarchists, but who, in writing for

Białystok, existed a set of printing letters for the Russian-anarchist paper Anarkhiya, which was edited by someone under the pseudonym "Angel". The set of letters for both papers was destroyed by Tsarist police and thugs (Nedava 1974: 77; Goncharok 1997: 9).

$3^{\circ}$ In A. L. and V. L. Gordin: Manifest pananarkhistov, Moscow I9I 8 and in Br. Gordiny: Nichego ne zabyli i nichemu ne nauchilis, in: Anarkbist, 22.10.1917, I f. (transl. into English in Avrich I973: 49-52, 55) the brothers described pan-anarchism as a comprehensive program directed against five primary forms of oppression. Five ideals were posited: I.) the political ideal of society's liberation from government, 2.) the economic ideal of the workers' liberation from private property, 3.) the pedagogical ideal of children's liberation from authoritarian education (which they called "pedism"), 4.) the anticolonial ideal of the liberation of all nations from empires ("national-cosmopolitanism"), and 5.) the feminist ideal of women's liberation from misogyny and domestic domination (ibid.: 49).

${ }^{31}$ Goncharok 1997: I 2-I4; LNYL: I39 f.

32 Avrich I967: 2 II.

33 The details given on the year of Gordin's emigration vary: Joseph Nedava refers to I924 (I974: 73), LNYL however indicates I926. Gordin was to be sent to the Manchurian border according to an order of the director of Cheka Felix E. Dzerzhinsky, but H. Kropsoy pled for Gordin and he could flee from Russia (Goncharok 1997: I 3 ). Nevertheless, Gordin started writing Gruntprintsipn fun Idishkayt in Shanghai in 1927 (1938: ii). 
Fraye Arbeter Shtime, an organ that considered itself exclusively anarchist, thereby situated their arguments within an anarchist counterpublic space, demonstrating an "openness to radical ideas" typical of Yiddish socialist circles. ${ }^{34}$ Just as the newspaper was open not only to self-proclaimed anarchists but also to socialists, Marxists, Labour Zionists, and literary critics and Yiddish educational reformers of various stripes, so the Jewish anarchists themselves did not always define themselves as "anarchist", but rather shifted between socialist and libertarian identifications according to context. With this openness Fraye Arbeter Shtime played a crucial part not only for anarchists, but also for Jewish workers in North America. It constituted one of the few institutionalised forms of Jewish anarchism - the press, fraternal societies (faraynen), modern schools and cooperatives and concurrently fulfilled a social function: newspapers and societies were focal points for immigrants, providing the space to elaborate Jewish self-perceptions. The paper was a highly productive part of the "Yiddishist" culture movement; it was the most long-lived Yiddish anarchist periodical and along with the daily Forverts, one of the most long-lived Yiddish papers per se. ${ }^{35}$

It cannot be underestimated how dependably Fraye Arbeter Shtime served as a bridge between emerging and established Yiddish writers; along with the London Arbeter Fraynd and Zsherminal, it played an important role in establishing Yiddish literature by the end of the $19^{\text {th }}$ and in the first decades of the $20^{\text {th }}$ century. The prolific translation work of Yankev A. Merison (a.k.a.

34 Michels 2005: I03. Kathy Ferguson develops the concept of the "anarchist counterpublic" in the context of an analysis of Emma Goldman's militant career; while this is never simply a universal "public space", it is a space within which anarchists "rubbed shoulders with [those of] other political dispositions, inciting conversations among radicals and liberals over shared agendas such as freedom of speech or access to birth control", extending beyond the intimate circle of "friends, acquaintances, and identifiable [anarchist] groups [. . .] into the realm of strangers" (2010: I97).

35 Cohen I945: 430-43, 43I; Zimmer 2015: Ch. I, pp. 32-37. "The Fraye Arbeter Shtime played a vital role in the Jewish labor movement in America; and throughout its long life it maintained a high literary standard, featuring some of the finest writers and poets in the history of Yiddish radical journalism" (Avrich I988: I 84). 
Jacob Maryson $)^{36}$ was published alongside that of fine Yiddish writers, even if they did not consider themselves anarchist. This inclusiveness was felt as a strong connection among Yiddish anarchists. Yoysef Kahan (a.k.a. Joseph J. Cohen), an administrator of the paper, spoke of their habit of referring to themselves as FASh mishpokhe (the "FASh family") at several occasions. The term was used to describe friendship and mutual respect. ${ }^{37}$

Not in spite of but because of this mutuality, the tensions and antinomies of anarchism laid the foundation of the debate we

${ }^{36}$ Merison (I866-I94I) was a Yiddish and Hebrew philologist, editor of Varhayt ("Truth"), Di fraye gezelshaft ("The Free Society"), Undzer kind ("Our Child" - a pedagogic journal published by Kultur lige). He also wrote for Arbeter fraynd ("The Worker's Friend"), Ovnt tsaytung ("The Evening Times") and Tsukunft ("The Future"), drew up the controversial brochure Anarkhizm un politishe virklekhkayt ("Anarchism and Political Reality"; New York I906), in which he argued pro participation in elections. Others like Rudolf Rocker and Shoel Yanovski strongly opposed this (Goncharok I997: II). Furthermore, Merison translated C. Darwin, K. Marx, H. Spencer, M. Stirner, E. Malatesta, P. Kropotkin, J. S. Mill, H. Ibsen and J. A. Thompson, published own articles on philosophy, sociology, physiology and pedagogy, and thus enriched vocabulary and style of the Yiddish language. He was founding member of the Kropotkin literatur gezelshaft ("Kropotkin Literary Society") in I9I3 (ibid.). This cooperative publishing house printed socialist and anarchist masterpieces in Yiddish until I930.

37 Kahan I945: 430. Kahan named members of the editorial board (among others D. Izakovits, B. Aksler, Dr. Globus, Dr. Dubovski, A. Mints, Sh. Farber, L. Finkelshtayn, Dr. Michael Cohn, Hirsh Rayf), contributors from cooperative circles (among others Dr. Y. A. Merison, Vm. Natanson, Dr. Herman Frank, Abba Gordin, Gr. Raiva, S. Retap, S. Deyvidson, Vm. Shulman, A. Frumkin, R. Lazarson), from non-cooperative circles (among others A. Almi, A. Bukshteyn, B. J. Bialostotski, I. Borodolin, B. Glazman, I. B. Goldshteyn, I. Hurvits, Dr. Zeligman, M. I. Kheymovits, Daniel Tsharni, Leybush Lehrer, Khayim Liberman, Yankev Milkh, L. Malakh, Nakhmen Mayzel, Rubn Fink, Alter Epshteyn, A. M. Fuks, Oskar Kartazshinski, I. Kornhendler, L. Krishtal, Melekh Ravitsh, I. Rapoport, B. Rivkin, Dr. Yankev Shatski), from abroad (Rudolph Rocker, M. Korn, Dr. Max Nettlau, Dr. I. Rubin, Dr. I. N. Shtaynberg, Alexander Berkman, Voline [Vsevolod Mikhailovich Eikhenbaum], Vm. Tsukerman) and at festive occasions Yoysef Opatoshu, Ben-Tsien Goldberg, Aaron GlantsLeyeles, Dr. Khayim Zshitlovski, Halper Leyvik, Dr. A. Mukdoni, Shmuel Niger, Tsivion, Dr. Koralnik, Hillel Rogof, Avrom Rayzen. Cartoonists and poets like Rokhl Okrent, Bimko, Deyksel, D. Gisnet, Yudkof, Tsinkin were innumerable (ibid.: 43 I; first names written out according to the source). 
will describe below. It should not be surprising that religion was not in every case part of the anarchists' prizing of differences..$^{38}$ To illustrate the range of ideas that are to be taken into account when speaking of antireligiosity, we will examine antireligious identifications by six authors. The second part of this essay addresses at least eight identifications, whom the antireligious derisively referred to as "religiously inspired souls" (di religyez geshtimte), 39 "traditionalists" (pro-traditsyonistn), ${ }^{40}$ "seekers after God" (got-zukher), ${ }^{4}$ the "Jewish-only philosophers" (di noryidishe filozofn), ${ }^{42}$ "leaders of the religious-ethical-socialist circles [with] their empty phrases", ${ }^{43}$ "part-time returnees to tradition" (di konyunktur bal-tshuves) ${ }^{44}$ rushing "back into the ghetto", ${ }^{45}$ or "pious" (frumakes), ${ }^{46}$ "reactionaries", ${ }^{47}$ and "hypocrites". ${ }^{48}$ Such phrases defined the ideal Epicurean freethinker by contrast with these supposedly traitorous backsliders. It will be interesting to note to what extent religious anarchists ${ }^{49}$ applied different argumentative strategies in response to their opponents, and which explanatory demands were met in each case. Later, we will remark

38 "Anarchism, for all its international pretensions, for all its faith in the unity of mankind, has always been divided into national and ethnic groups. [. . .] Nor should this be surprising. For anarchists, cherishing diversity against standardization and conformity, have always prized the differences among peoples - cultural, linguistic, historical - quite as much as their common bonds" (Avrich I988: I76).

39 Sh. Rabinovitsh: FASh I6.09.38, p. 5 .

$4^{\circ}$ A. Gelberg, in: FASh 23.6.39, p. 3.

4 I V. Nayman: FASh 29.07.38, p. 3; Sh. Rabinovitsh: FASh I6.09.38, p. 5.

${ }^{42}$ Sh. Rabinovitsh: FASh I6.09.38, p. 5. Here, Rabinovitsh addresses Shmuel Niger, Abba Gordin, Mordechai M. Kaplan, Shlomo Bager, Kalmen Vaytman, Itskhak Unterman, drawing an analogy to the English philosopher George Berkeley (born I685), a proponent of 'subjective idealism' and immaterialism ('to be is to be perceived').

43 V. Nayman: FASh 29.07.38, p. 3.

44 Sh. Levin, in: FASh 28.3.4 I, p. 5.

45 V. Nayman: FASh 29.07.38, p. 3.

${ }^{46}$ T. Eyges, in: FASh 2I.3.4I, p. 3. The suffix -akes is attached to frum (pious) and adds a strong derogatory sense.

47 Ibid.

$4^{8}$ Ibid.

49 The term is not used as self-identification. It is a provisional term applied to reduce complexity. 
on the role that religious anarchists played for their communities and on the assumptions made by observers questioning the compatibility of religion and anarchism.

\section{Varieties of antireligious polemics}

The antireligious lines of reasoning present in these debates attack both religion and nationalism from a universalist point of view. However, the critique sharply distinguishes religion from ethnicity and conceptualizes religion as a system of private thought only. Public, social thought with bearing on the world of practice e.g., philosophical, ethical, or legal teachings - is thus also to be rigorously set apart from religion; religious practice is of interest merely in its (negative) effect on the human educated mind. Religion is seen as detrimental to the world of politics properly conceived, since it is organized and advanced by reactionary forces in history. These arguments are unique in applying Feuerbachian terminology and clearly separating religion from ethnicity in the frame of Jewish traditions.

Such lines of reasoning can be found in the Marxist position brought forward by V. Nayman, ${ }^{50}$ who equated religion with irrationality and superstition. Nayman contrasted religion to science, declaring that the call to return to religion on the part of "religio-ethical-socialists" was a call to return to "the ghetto". Accordingly he saw religion as narrow-mindedness, whereas a departure from Jewish and religious education meant opening up people's minds. Here, a universalistic concept of socialism close to Marxism can be detected, one that depreciates Jewish religious and ethnic particularity, which was equated with the backwardness of the ghetto. ${ }^{51}$ Nayman supported secular, socialist and

50 V. Nayman: FASh 29.07.38, p. 3. Nayman, whose first name, always abbreviated, has yet to be identified, used "Marxism and the sciences" as synonyms, thus placing himself on the terrain of scientific socialism.

${ }^{5}$ Marx's concept of religion was ambivalent and thus allowed numerous interpretations. It firstly was directed - according to the prevalent antiSemitic Zeitgeist - against Jews, equating a Jewish "worldly religion" ("weltlicher Kultus") with "huckstering" ("Schacher") and self-interest ("Zur Judenfrage" 372; "On the Jewish Question" I70). It secondly treated both Jewish and gentile religion as equally false. The critique was directed 
especially non-Jewish education. He argued against those who held, with Almi, ${ }^{52}$ that blind trust in science was to blame for Nazism and the persecution of the Jews. Instead, science was to ease people's lives.

Nayman attacked the concept of Jewish chosenness and compared it to the anti-Semitic perception of Jews as a separate group. Instead of locking themselves behind the walls of a ghetto, ${ }^{53}$ the Jewish people should act in concert with the rest of humanity in the face of the crisis of capitalism. The author called for solidarity and a unified struggle for true socialism in which every human being might "shine like a brooch's precious stone", emphasizing purportedly 'common' interests and the need for international struggle in the face of the capitalist crisis.

A similar strategy was applied by Thomas B. Eyges, who identified ethnic separatism as a problem, accusing "the religious" of demanding ethnic unity. ${ }^{54}$ To Eyges, the call "back" to religion was not only chauvinistic, but also insolent, especially in "times

against any kind of religion, as Marx wrote in the introduction to Die Kritik der Hegelschen Rechtsphilosophie. Here, religion was the sigh of the oppressed ("Seufzer der bedrängten Kreatur"), a sedative creating dependence and addiction while deterring from protest and revolution (MEW, vol. I: 378). In a different context Marx claimed that he was caricaturing economic relations, not persons (I 867/I998: I00; see also Traverso I994).

${ }^{52}$ A. Almi (Eliye-Khayim ben Shlomo-Zalmen Sheps, a.k.a. Eli A. Almi, I892-I963) - an agnostic writer, author of numerous books, satirist and humorist, folklorist, poet and polemicist - wrote for the Yiddish dailies Forverts and Der Tog as well as the satirical weekly Groyser Kunds and the literary journal Tsukunft, but contributed primarily to FASh from 1923 (LNYL vol. I, I०8-9).

53 One of the leading scholars on the history of Yiddish language, Max Weinreich, wrote: "[. . .] in Yiddish, until the days of Hitler, geto was a foreign-sounding learned word, never much in vogue." (I968: fn IO). Instead neutral terms like di yidishe gas or di gas (literally "the Jewish street", "among Jews") were in use. In this respect, Nayman employed a term that resonated with the assumptions of the Nazi extermination policy. It is worth noting that the mutual accusation of Nazism not only worked on the level of polemics to shame the opponent, but also was a widespread concern within I930s and I940s romanticism.

${ }_{54}$ T. Eyges, in: FASh 2I.3.4I, p. 3. Tuvye Borekh (Thomas B.) Eyges (I $875^{-}$ I960) was author of Beyond the horizon: The story of a radical emigrant, Group Free Society, Boston 1944, and ran a weekly column in FASh ("Correspondences of a traveler"; LNYL, vol. I, p. 57 f.). He also wrote 
like ours", when humanity needed to help all the victims of war. ${ }^{55}$ Here again, common and natural interests were held up for contrast with the supposed divisiveness of others. Eyges reminded his readers that most wars, persecution, and violence had been triggered by religious ideas. In this sense, religion was seen as cause of war, not a solution. Its influence on people's minds was especially dangerous when it penetrated into Yiddish secular schools. It was obvious to Eyges that religious zealots punished dissidence and called for sanctions against freethinkers and atheists. ${ }^{56}$ In this case, the author no longer lamented the failure of transnational unity as a political strategy, as did Nayman, but identified religious ideas as the roots of violence, persecution and punishment. To Nayman's line of reasoning, which saw particularities as incompatible with universalism, Eyges added a second notion: religion exercised domination by imposing sanctions and acting on people's minds - a point to which religious anarchists were quick to respond.

Shlomo Rabinovitsh ${ }^{57}$ and A. L. Goldman ${ }^{58}$ both added a widespread anti-authoritarian critique of religion. ${ }^{59}$ Rabinovitsh viewed religious Yidishkayt in political terms as a right-wing tendency within the radical community. God, for Rabinovitsh, represented an authoritarian king who creates and supervises the world, defines sin and good deeds (mitsves), and is petty-minded enough to arbitrarily reward or punish human behaviour. To this perception of God as authoritarian, Goldman added an attack on theodicy,

for Arbeter Fraynt, the first London-based Yiddish anarchist paper, which often published anti-religious articles.

55 T. Eyges, op. cit.

${ }^{56}$ Some letters in the I904 debate likewise referred to a threat which pious Jews (e.g. by sabotaging meetings) posed to free thinking (Polland 2007: 395).

57 The anti-religious writer Shlomo Rabinovitsh has yet to be identified. He is not listed as an author for FASh in Kahan I945: 430-43.

${ }^{58}$ It is conceivable that this was Abraham Leib Goldman (I885-I970). Born in Szreńsk, Poland, Goldman taught in Canada (from I907) and the US (from I9I 2 in New York City) at Yiddish secular schools, like Sholem Aleichem shul and Arbeterring. He developed a Yiddish stenographic alphabet (see Yivo archives, RG 632).

59 Sh. Rabinovitsh, in: FASh 16.09 .38 , p. 5.; A. L. Goldman, in: FASh O3.12.43, p. 3 . 
questioning the senseless, blind, even willing suffering of God's righteous followers. He asked why a supreme power would need to crush the smallest little worm, and the "bird with the worm" 60 too. Here Goldman referred to the biblical narrative of the binding of Isaac as illustrating the cruelty of this divine authority. ${ }^{6 \mathrm{I}}$

Goldman took a stand against an agnostic argument made by A. Almi defending science against faith in order to establish yet another position within an anarchist critique of religion. ${ }^{62}$ Almi had earlier raised a question concerning causality (urzekblekbkayt) in creation which, in Almi's view, had not yet been resolved in the sciences. Almi held that the assumption that all natural processes could be explained by natural law would contradict the assumption that their creation was coincidence. Cosmic order could be interpreted as regularity - a plan by "someone" of whom one knows nothing. For Goldman, responding to Almi, this was merely pilpl ("splitting hairs" - the rabbinical method of a detailed discussion of Talmudic issues); these questions were to be solved by theology, not by science, thereby distinguishing between their domains of competence and jurisdiction. Since science and knowledge were in a state of constant progress, Goldman suggested, the answers to what could not yet be explained could be safely postponed. He drew examples from mass communication and transportation - a

${ }^{60}$ A. L. Goldman, in: FASh 03.12 .43$, p. 3.

6r The classic example is Job's suffering in the Book of Job. It is noteworthy that antireligious critics focused on specific biblical stories that presented mythological accounts of the world, as in the Creation (Genesis I, I-2), and/or an image of God as cruel or vengeful, as in the binding of Isaac (Genesis 22,I-I9), the stories of Babel (Genesis II,I-9) and the Deluge (Genesis 8,I-I4). In these episodes, human beings are made to be fearful of God, which antireligious thought seized on as evidence that religion derived from fear and ignorance of the forces of nature. This point is addressed by religious anarchists. Abba Gordin is one of the few to answer the critique of ritual sacrifice, in stressing the outcome of the story of the binding of Isaac, which he read as a prevention of death (Gordin I939/I9I9: ro9 ff., esp. I 18).

62 Almi argued that the universe, including everybody and everything (mit hak un pak), was just a piece of human thought. For Goldman, however, it is not enough to "not know" about the existence of God. He was insulted by Almi's claim, that earlier generations (an amokiker mentsh) might have known "more" than present thinkers (A. Almi, in: FASh 05.I I.43, p. 2). Goldman then accused Almi of idealizing the past. 
century earlier, no one would have expected to be able to fly - to respond to Almi's emphasis on the uses of scientific knowledge for waging war and suppressing dissent. ${ }^{63}$

In this case, one could argue, it was indeed religion, understood as the blurring of scientific reason, and not only domination, that constituted the core of what was to be rejected. Almi's wish to supply answers to the unresolved question of causality in science - which was linked to an anarchist critique of knowledge (Erkenntniskritik) - certainly suggested that not only power, but also knowledge and its origins were crucial in the debate illustrated here. But Goldman circumvented the problem, deferring questions about the as-yet unknown to the future, and instead stressed the question of how God could allow human suffering thereby returning to the problem of domination and human subordination under a divine will as the core argument against religion. The problem of why evil was prevalent in a world God created remained equally unresolved, and again, raised the spectre of God as an arbitrary authority.

The most vigorous argument against religion was presented by Shlomo Sayman, who attacked the authoritarian behaviour of "the new believers". ${ }^{64}$ The author drew up two exclusive and opposed positions: one side represented by rabonim (rabbis), threatening and punishing human joy, who regarded the Tanakh,

${ }_{63}$ The role of science in society was heavily debated not only by Goldman and Almi. Here one finds problems that were addressed by Max Horkheimer and Theodor W. Adorno touching the intertwined productive and destructive elements of democratization and mass culture in their Dialectics of Enlightenment, a social critique published in I944. The hypothesis in the book is reminiscent of Almi's - that the scientific rationality produced by the Enlightenment was no great improvement over the "mythic fear" it sought to banish, and that a purely instrumental reason, stripped of ethical commitments, turned into barbarism (Horkheimer; Adorno I967, I 6, 30, and passim).

${ }^{6}$ Sh. Sayman: FASh I3.I I.I942, p. 3. Sayman (I895-I970), a dentist and teacher of Hebrew, was very active in the Yiddish secular school movement; he was president of the Sholem-Aleykhem Folk-institut between I940 and I955. Apart from this, he was vice-president of the New York Yidish-Etishe Gezelshaft, established by Abba Gordin. He wrote for FASh, Di Tsayt, Tog and Dos Idishe Folk (LNYL, vol. 6, 4I3-I 5). Here, he took a very sharp stand against public displays of religious belief. 
the Hebrew bible, as absolute knowledge, which was not to be modified or seen as a reflection on historical events. The other side was represented by the Epicurean press, that provided the privilege to print without acting out censorship, even if it would not agree with what was being printed. After emphasizing tolerance towards "true" pious Jews, Sayman distinguished between modest Jews, not acting out their beliefs in public, and modern returnees to tradition (bal tshuves). For him, the "true" religious Jews were harmless compared to the formerly radical, who now "paraded" in public, dressed in arbe-kanfes (traditional cloth). The "newly religious" hypocrite was even more traditional than the harmless, naively pious Jew, who in any case did not exhibit religiosity in public. ${ }^{65}$

Sayman went beyond the question of authority to question the visibility of religious behaviour in public space. First he complained that former radicals now "carry their money to Lubavitch" ${ }^{66}$ How could writers contribute fine Yiddish pieces to the radical press, then pray three times a day, keep kashres (dietary laws), and observe the Sabbath? What is remarkable in this line of argument is Sayman's concern for literary production. He feared for what Pierre Bourdieu would call the radical community's cultural capital - "fine Yiddish writers" - as much as its monetary resources. Accordingly, he urged a separation between the "truly" pious and the "former radical", whom he asked not to shout too loudly and parade with false piety. Thus, in a unique manner, Sayman combined the rhetorical strategies used by most actors in this highly diverse field - blaming, accusations, and dramatization - in order to now silence religious actors and exclude them from the public space of the Epicurean press and thereby from its discourse. Sayman's distinction and exclusion from the press describes a zone

${ }^{65}$ Ibid. The Forverts-debates equally displayed rhetoric moves to define how a true believer should act: "a true religious idealist would stand up for his ideas and trust in God's protection" (Polland 2007: 385-7). Obviously Sayman here contradicted the claim that 'truly' religious Jews posed a threat to free-thinkers.

66 Ibid. Chabad-Lubavitch is a collective term for adherents of Menachem Mendel Schneerson (I902-I994), the son-in-law of Rabbi Yosef Yitschak Schneersohn (I880-I950), who migrated to the US in I940 and built the movement to which Sayman referred. 
of tolerance - a private sphere; but it is when belief is acted out in public that it becomes subject to criticism as "reactionary", "chauvinistic" and even "regressive" ${ }^{67}$ Thus, a nonconformist was identified by Nayman against those who were merely to be tolerated (or yet to be persuaded). ${ }^{68}$

\section{Religious anarchist subversions}

Following Friedrich Schleiermacher's distinction between "religion" and "religiosity," Nathan Goldberg, ${ }^{69}$ Abba Gordin, ${ }^{70}$ Tsvi Kahan $^{71}$ and Khayim Ashli (Ashley) ${ }^{72}$ held that religion was the institutionalised, "frozen" form of the religious feeling; it was a "fossilised" personal connection to higher meaning. ${ }^{73}$ In this sense,

${ }^{67}$ Ibid.

${ }^{68}$ Nonconformity and nonconformism are terms discussed by the graduate school Religious Nonconformism and Cultural Dynamics (2009-2014) at Leipzig University. The terms help to distinguish between what is open to question and what is not.

69 N. Goldberg, in: FASh I 5.OI.43, p. 2. In his article "Social doctrine that turns 'humanity' into a religion" Goldberg addressed the rise of positivism as a religion. In addition to the debate illustrated here, the author contributed to the volume "History of the Jewish labor movement in the United States" cited earlier (N. Goldberg, in Tsherikover, op. cit.).

${ }_{70}$ A. Gordin, in: FASh I 5.I I.I940, p. 5.

${ }^{71}$ Ts. Kahan: FASh 4.II.38, p. 5. Kahan addressed Shlomo Rabinovitsh by referring in the title of his article to "Those Who Ask: What Good Is Religion?"

${ }^{72}$ Kh. Ashli, in: FASh I3.Ir.r942, p. 5. Khayim Ashli is one of the pseudonyms used by A. Almi, but it is unclear, why Almi wrote under different pseudonyms for Fraye Arbeter Shtime.

73 Ibid. An analogy to the hidden energy and heat in coal allows us to conceptualise religion as a system of thought that might release an ancient revolutionary spirit. The motif could be taken from the Zohar, a Jewish mystic source (Zohar III, 70a). These characterizations of religious spirit also strongly parallel Gustav Landauer's “spiritual atheist” conception of dynamic Geist as existing in tension with the symbolic structures erected to contain it in history: "Wherever men have been, they were [. . .] held together by a common spirit, which is a natural and not extrinsically imposed compulsion [...]. But this natural compulsion of the unifying quality and common spirit, until now in known human history, has always needed external forms: religious symbols and cults, ideas of faith, prayer rituals or things of this sort. Therefore spirit is in the nations always connected with unspirit, and deep symbolic thinking with superstitious 
religion reflected human longing for higher meaning - education, culture, and civilization. Religiosity was rooted in this striving, not in fear of God or nature. ${ }^{74}$ Rather than regarding religiosity as entailing an abdication of choice, they reinterpreted it in ways that stressed the individual's responsibility. One of these reinterpretations connected science to an ethical belief system. The other redefined tradition in a highly modern, voluntaristic manner as a system of core values that were to be chosen by individuals.

Whereas the antireligious polemicists were sometimes concerned to isolate religion (Judaism) from secular ethnicity (the Yidishkayt of language, literature, and culture), the defenders of religion did not draw a clear distinction between religion as system of thought, Jewish traditions and ethnicity. Here, religion and the Jewish folk are often represented as intertwined categories of belonging. Religion can be defined as the source of spiritual meaning, philosophical and ethical teachings, art and literature and - most importantly - as way of living with both individual

opinion. The warmth and love of the unifying spirit is overshadowed by the stiff coldness of dogma. Truth, arising from such depths that it can be expressed only in imagery, is replaced by the nonsense of literalness. This is followed by external organization. The church and the secular organizations of external coercion gain strength and grow continually worse: serfdom, feudalism, the various departments and authorities, the state. This leads to an eventual decline of spirit among and over the people, and of the immediacy that flows from the individuals and leads them to unity" (Landauer I978: 32-33).

74 Ts. Kahan, op. cit. In Abba Gordin's writings we find a critique of what Max Weber described as the routinization of charisma by religious officials (Weber I979: 246). Gordin intended to keep an original religious feeling and called to the prophets' revolutionary spirit. Respect and fear of yourself was fear of God. Idolatry was to not serve one's own interest (Gordin I93 8: 65). Where Stirner posited a concept of the Einzige or Ego possessing its own 'truth' (Buber 2002: 96), Gordin described the $I$ as the knowledge of the Wise (medat harakhamim, Gordin I938: 65), a treasure-house (ibid.: 45), provided with a prophetic gift of sensitivity and presentiment (ibid.: 9I). The priests (kohanim) ritualised, mechanised the service; the prophets rejected these externalizing doctrines and favoured a vivid, dynamic, ethically based unity: "ethos instead of rite; solidarity, equity [yoysher] and justice [tsdoke] instead of uniformity!" (ibid.: 277). To be a radical Jew meant to be a fighter for equity and justice and to follow the prophetic sense for justice (yoysher-gefil) (Gordin I940: 248). 
and social implications. In rare cases, Judaism is described as folk only by excluding religious and traditional contents. ${ }^{75}$

Herman Frank ${ }^{76}$ contended that science would be inferior to tradition if it was without ethics, whereas ethics had its foundation in higher meaning - here linked to the Jewish religious tradition. The question of knowledge, progress and science ${ }^{77}$ was a "psychological”, "internal” and "humanistic" issue. In response to Goldman's antireligious argument, Frank enlisted Spinoza, David Hume and Immanuel Kant in order to shift the domain of competence and jurisdiction: not theology but philosophy had addressed the problem of causality and posited a rational concept of deity. Menakhem Boreysho ${ }^{78}$ went further than Frank in embracing the Jewish religious tradition: he argued that religiosity provided

75 E.g. Yitskhak Finkelshtayn and Anatoly Gelberg (Türk 20I4, ch. 4.3).

${ }^{76}$ H. Frank, in: FASh 3.I2.I943, p. 5. Herman Frank was editor of FASh (1940-I952), author of the small brochure Anarkbo-sotsyalistishe ideyen un bavegungen bay yidn. Historishe un teoretishe aynfirung, Paris/ Tel Aviv I95 I (Anarchist-socialist ideas and movements among Jews. Historical and theoretical introduction) and editor of Shaul Yanowsky's Ershte yorn fun yidishn frayhaytlekhn sotsyalizm, New York I948 (First Years of Jewish Libertarian Socialism). He became interested in the history of Hasidic Judaism and translated Martin Buber and Gustav Landauer to Yiddish. In this article of 1943 he appraised a book by the Marxist historian Raphael Mahler (Haskole un Khsides in Galitsye, I942), which later was translated into English (Hasidism and the Jewish Enlightenment. Their Confrontation in Galicia and Poland in the First Half of the Nineteenth Century, trans. Eurene Orenstein et. al., Philadelphia I985).

77 One year before, Khayim Ashli had stated that scientists, even if starting from similar presuppositions, always came to different conclusions. Ashli was not specific, but might have referred to different interpretations of statistical data. It would not be contradictory if even Darwin visited a church, he concluded (Kh. Ashli, op. cit.).

${ }^{78}$ M. Boreysho, in: FASh I 5.03.I940, p. 5. Boreysho (I888-I949) was a teacher at Yiddish secular schools (Arbeterring) and wrote for the communist Frayhayt, until it justified the 1929 anti-Jewish riots in Palestine. He also published in Tog, Haynt, Tsayt, FASh and Literatur un Lebn. Overlapping ideas can be found to the prevalent introspectivist art movement (Inzikhistn) in the city of New York. According to the poet Yankev/ Jacob Glatshteyn, Boreysho's religious poetry was not seeking God in the "common" manner, but rather in metaphorical ways (LNYL, vol. I: 249). Boreysho was not necessarily an anarchist. With regard to spirituality, he took a stance close to that of Abba Gordin. 
meaning, stability and ethical values that instrumental rationality did not. This author expressed his valuing of subjectivity and individual perception by taking an esoteric position towards poetry, stressing conscience, meditation and the study of the inner self. 79 Love for humanity was, in the terms of the traditional ("old") Jews, love for Shekinah (the divine presence on earth). ${ }^{80}$

A. Almi, too, held that truth was a matter of faith: the only thing one knew was what one believed to be true. ${ }^{8 \mathrm{I}}$ In support of this proposition, Almi offered two lines of reasoning - one from principle and one of a personal nature. In the first place, human knowledge would always be limited; the origins of life remained a mystery. The possibility of coincidences was denied by scientists, who presupposed regularity in the laws of nature. Almi thereby took an agnostic stance in rebuttal of A. L. Goldman's argument that a belief in higher beings was superstitious. Secondly, while firmly proclaiming that he believed in God, and, he added, in a higher power and universal reason, in view of the dire circumstances of the present time, he voiced his disappointment in God. ${ }^{82}$ For Almi, thus, the problem of human suffering did not necessarily lead to a blind or abject acceptance of God, as Goldman thought, but would rather lead to a dispute with God. Almi went on to question and reject the orthodox approach to

79 The 'internal' and 'psychological' seemed to be of high importance. One can find overlapping ideas with literary artists, Inzikhistn (Introspectivists), of the I930s and I940s. Knowledge was seen as an introspective process and a study of the inner self, e.g. by Shea Tenenboym. Tanakh formed part of world literature; it was intimate and lyrical, showed social conflict, depicted loving, suffering, patient or just human heroes (Sh. Tenenboym, in: FASh 8.I 2.44, p. 5). We find what Max Weber described as sanctification of everyday life and a glorification of the simple ways of living (Weber 2005: 4I3-47I).

$8 \circ$ M. Boreysho, op. cit.

${ }^{8}$ I A. Almi, op. cit. As he later wrote: "All men have faith. There are no unbelievers. Even the atheist has faith. His faith, however, instead of being bound up with God, adheres to nature - which actually implies faith in an entity synonymous with that of God" (I947: 38).

${ }_{82}$ Almi makes the traditional confession of faith, starting with ani maymen be'emune shleyme ("I believe with a perfect faith"). Other authors, describing the atmosphere of the time, speak of ani-maymens (confessions of faith) and bal-tshuve-shtimungen (tendencies to return to God). 
God's authority alike, wherein one could not believe that anything happened without His will. The contention was, if one believed so, one must concede that evil derived from God as well. Almi's response to human suffering was an individualistic interpretation of responsibility and belief: violence, just like domination, was enacted by individuals. Political authority arose from man, not from God. ${ }^{83}$ Gangs and thugs persecuted Jews in those days. Against them, he argued that one may hold a sider (prayer book) in one hand and - being responsible for one's own defence - a gun in the other. ${ }^{84}$ In this respect, Almi subverted the prevailing picture of a submissive believer, redefining it in order to legitimise religiosity, and in so doing, provided new grounds for anarchists to change their hostile stance towards religion.

Similarly, Shmuel Levin argued against both knee-jerk antireligiosity and thoughtless religious piety. ${ }^{85}$ In his view, anarchists should not transplant Jewish orthodox exegesis of Tanakh into their own approach, and instead should treat the scripture as historical documents. The Tanakh and its rich translation into Yiddish by Yehoash ${ }^{86}$ should be taught as literary work in Yiddish

${ }^{83}$ It is worthy to note, that emancipation and secular education could be seen as gzeyre (anti-Jewish decree) by traditional Jews and Hasidim. The rejection of civil and bourgeois emancipation among Zaddikim ("just and pious men”, usually leaders of Hasidic groups) like Israel Kosenitzer, Jakob Isaak Lubliner and their adherents, not only entailed the rejection of equal rights, but also of polonisation, military service, and secularization - meaning the loss of communities' relevance and the loss of religious knowledge (Dubnow I922: 276 f.).

${ }^{84}$ This picture was one strategy to encounter prejudice by telling from a photography of an orthodox Jew and litvak (a Lithuanian Jew stereotyped as strictly rational Talmud student), who was well-read in worldly literature, holding not only a sider but also a weapon (A. Almi, in: FASh II.IO.40, p. 5).

${ }^{85}$ Sh. Levin, in: FASh 28.3.4 I, p. 5. See for the diametrically opposing view against an exegesis of Tanakh the example of Sh. Sayman, op. cit. (Haym) Shmuel Levin (I890-I959), who was in Berlin I920-I934 and migrated to the US in 1936, wrote in New York for Dos naye lebn, Di Tsukunft, Morgen-Zshurnal, Tog, the communist Ikuf and Hamer and for FASh. His work was translated into Polish, German, English, French, Dutch and Hebrew (LNYL, vol. 5, 298-300).

86 Sh. Levin, op. cit. Yehoash, a.k.a. Solomon Blumgarten (I870-I927), as a "Yiddishist," not only translated the Bible into Yiddish and co-authored 
secular schools. Levin's argument for a different way of engaging with tradition is reminiscent of Hasidic motifs: he promoted enthusiasm for a belief that resisted institutional structure and demanded subjective, intuitive understanding of the feeling and "taste" of Khumesh (Torah). ${ }^{87}$ Against the pious Jews, he suggested not taking the commandments literally; conversely, he advised radicals not to rush away from Tanakh too hastily. This act committed in the heat of the moment was not well considered and contradicted the true spirit of freethinking. Levin also addressed the classic anti-authoritarian critique of traditional learning in kheyder (religious elementary school), applying the same strategy as Almi: authority rose from human acts, not from God. Levin shifted the burden of authority and responsibility onto the teachers: these melamdim (religious instructors) simply had been lousy educators. ${ }^{88}$

Khayim Ashli similarly used the anarchist tactic of claiming the position of the true freethinker for oneself. ${ }^{89}$ Ashli emphasised what had been established by Shmuel Levin to weigh up advantages and disadvantages of the Jewish tradition. Thus, in the spirit of what he considered true freethinking, he warned against turning antireligious ideology into a dogma, a new religion..$^{90}$ To make more careful distinctions, to select what was progressive and what

a dictionary of Hebrew terms and expressions in Yiddish, but also was a poet and editor of Tog.

87 Sh. Levin, op. cit.

${ }^{88}$ In fact, this view on melamdim and kheyder was a widespread topos among thinkers of East European enlightenment and Yiddish writers. The classic critique was coined by maskilim like Perets Smolenskin (I $842-$ I 885 ) and Judah Leib Gordon (I830-I892), who brought up the use of corporal punishment symbolised by the kantshik (a stick) and the tight curriculum. Mendele Moykher Sforim (Sholem Yankev Abramovitsh, I835-I9I7) and Sholem Aleykhem (Sholem Naumovitsh Rabinovitsh, I 859-I9I6) - both classics of Yiddish literature - were equally promoters of modern education and wrote against the kheyder, a mode of education that had existed since I 7 th century.

89 Kh. Ashli, op. cit.

90 Similarly Shmuel Niger argued, a well-known literary critic, who claimed that so-called freethinking was only to break shabes (Shabbat) and kashres (the dietary laws) as pithy phrase and in a rather knee-jerk manner. Niger is quoted in V. Nayman, op. cit. 
to discard - this was, he argued, what the ignorant (ameratsim) in "our radical swamp" had failed to do. Tradition was to be chosen and selectively changed.

A. Gelberg and Yankev Levin addressed the Yiddish secular schools' curriculum, ${ }^{91}$ reconsidering the contents of the Jewish holidays and redefining them for educational purposes. Peysekh (Passover), Khanike (Hannukah) and Purim could be interpreted as celebrating a tradition of revolutionary liberation, as opposed to the New Year's observance, Rosh Hashone, and the Day of Atonement, Yom Kiper, which were religious "as seen from any perspective" and in their very essence. ${ }^{92}$ They differentiated between different kinds of holidays, to keep some and redefine their content, and distance themselves from the contents of the others in order to remain within an anarchist logic. Holidays, especially Shabes (the Sabbath), were to be interpreted in social terms as days of rest from work. ${ }^{93}$

Still, those authors who called for a reinterpretation of tradition did not speak with one voice. For instance, Gelberg criticised so-called "traditionalists" (pro-traditsyonistn) like Abraham Golomb, arguing that while holidays were reinterpreted in every historical period, the constant fact in Jewish history was the national, so holidays were to be seen as national holidays. Therefore,

91 A. Gelberg, in: FASh 23.6.39, p. 3; Y. Levin, in: FASh, I7.01.4 I, p. 7. Tony Michels explained in detail, that one central point of the Yiddish schools was to give secular and socialist education. Still, this did not exclude to teach Hebrew and Tanakh (Michels 2005: ch. 4, esp. 207-210). Naftali (Anatol) Gelberg (1894-1958), a Bundist and advocate of Yiddish education, taught in Toronto and New York City at the Yiddish secular schools (Arbeterring mitlshul and Arbeterring Perets-shuln) and wrote for socialist, here anarchist, and also general-interest daily papers like Keneder Adler in Toronto (LNYL, vol. 2, 30I-2).

${ }_{92}$ Y. Levin, op. cit. Yankev Leyb Levin (I884-I958), in St. Petersburg one of Simon Dubnov's students, was a Labor socialist (Po'aley Tsien), later territorialist, and pioneer for Yiddish socialist education in Warsaw and New York (Harlem). He wrote for Tsukunft, Tog, Idisher Kemfer, FASh, Sotsyalistishe shtime. It is interesting to note that Levin edited Oyfn veg, a series devoted to creating a codex (Shulkhn-orekh) for secularizing the Jewish tradition (LNYL, vol. 5, 276-8).

93 Cf. recent Reform theologians' attempts to reimagine "Sabbath, sabbatical, and jubilee" together as linking traditions of social justice and ecological balance (Waskow 2000, 5I). 
he suggested adopting a pragmatic stance and - as Almi and Shmuel Levin had argued - contesting the religious "zealots" (shvitspeltsn) monopoly over interpretation of the tradition. ${ }^{94}$ What is noteworthy here is that "tradition" could be interpreted both in religious and national terms.

In short, Yiddish-speaking writers for FASh who defended religion did so on grounds emphasizing religious pluralism within the Jewish tradition, which entailed an individual's responsibility to choose among these different concepts in Judaism. To the individual belonged the competence and jurisdiction over any redefinition of religious concepts and practices. At the same time, a particularistic notion of anarchism was stressed - a "specific" and intrinsically Jewish contribution to radical ideas was valued. Judaism was not seen as identical to Orthodoxy. On the contrary, it was the antireligious anarchists who endorsed an orthodox concept of God in assuming that God enjoyed sole authority over human action, while "believing" anarchists like Almi broke away from this deterministic concept, stressing self-responsibility. Thus, we might say, religious anarchists in the Jewish community embraced an individualistic concept of responsibility, which had been shifted to a supernatural power by anti-religious anarchists.

\section{Conclusion}

Writing from the perspective of the early I950s, just past the cataclysm that marks the period of our study, Herman Frank reflected that while "the initial stages of the movement in England and the United States" were indeed marked by " $[\mathrm{t}]$ he identification of Jewish Anarchism with atheism and anti-religious campaigns," that moment had gone: "With the passing of time [...] a more refined and profound approach to all kinds of problems concerning ethical and spiritual life became increasingly noticeable in the press and literature of the Jewish Anarchists, while the shallow and vulgar anti-religiousness of yesteryear rapidly declined and

94 Ibid. 
disappeared." 95 What were the consequences and implications of this transformation?

The debate illustrated here reflects the emergence of growing tendencies towards religiosity (bal-tshuve shtimungen) among Yiddish radicals during a time when Jewish anarchism was in decline. Joseph J. Cohen described the I920s and I930s as an ideologically "defensive" phase of the Yiddish anarchist movement, as anarchists were driven back by the influential communist and Zionist movements and by their own factionalism, uncertainty, and even disillusionment. ${ }^{96}$ Plus, the loss of a Yiddish reading radical audience may be attributed to immigration restriction laws in the I920s and to the devastating defeat of anarchism in the Spanish Civil War. ${ }^{97}$ Taking these ideological and historical changes into account, we observe in the I930s what Rogers Brubaker described as subsiding "groupness". ${ }^{8}$ These processes explain the subcultural dynamics perceived on both sides of the debate: antireligious actors and the "traditionalists" themselves described changes within the radical community. Religious Jewish anarchists had to locate themselves in relation to the prevailing atheist identifications of other Jewish anarchists. They sought to modulate the strong critique of religious and educational institutions derived from the East European Jewish Enlightenment. Religion

95 Frank 1954: 284-5.

${ }^{96}$ Cohen 1945: 528-9. Moyshe Goncharok explains the decline of Yiddish anarchism as a result of the disappearance of the experts and enthusiasts of Yiddish literature, of fiery speeches and Jewish workers' pride (1997: 7).

97 Zimmer 2015: 172-5; 196-205; 210-II.

${ }_{98}^{8}$ In describing the processes that shape identities, Brubaker suggests going beyond the level of mutual attributions and accusations to describe the categories being applied for perceiving the self and others. Categories can be assumed, claimed, circumvented, contested, subverted or simply ignored, and through this process of negotiation, identities are mutually allocated. Following Brubaker, we can analyse the "tipping and cascade mechanisms" of commonality, connectedness and "groupness" ("Zusammengehörigkeitsgefühl” - a term coined by Max Weber), avoiding imagining groups as monolithic units: "[S]ensitivity to the variable and contingent, waxing and waning nature of groupness [...] can focus our analytical attention and policy interventions on the processes through which groupness tends to develop and crystallise, and those through which it may subside" (Brubaker 2004: I9). 
as a group-building category was embraced when activists and editors were searching for a wider audience, as was the case during the Forverts in the early years of the 2oth century. We might also attribute the debates in Fraye Arbeter Shtime 30 to 40 years later to this search for a broader meaning of anarchism. Whereas earlier, radicals in groups such as the Arbeterring had pleaded for tolerance towards "Yom Kippur Jews" or "three-day-a yearJews," 99 however, now we find writers actively incorporating religion into a system of freethinking ideas.

Some similar argumentative strategies can be found on both sides of the debate in FASh. Nayman argued that anarchists should not react to Marxism in a merely reflexive manner, since such ideological prejudice ran contrary to the spirit of true freethinking. In turn, Khayim Ashli held that freethinking itself had been reduced to a dogma, an antireligious religion and fanatical belief system. These parallel rhetorical moves allow us to see, behind the antireligious/religious dichotomy, a shared pattern of anarchist identifications. Both antireligious and religious actors rejected "false" piety - assuring their self-location within the anarchist movement. Since it was the differentiation by Friedrich Schleiermacher between religion and religiosity that was referred to, one may conclude that spiritual traditions were closer to anarchism than others, such as institutionalised religions and the "fossilised" religious feeling. Abba Gordin strongly criticized the processes of institutionalization through routinization of the charismatic prophets' originally radical meanings.

Self-identifications as Jewish anarchists and as traditionalists required thorough legitimation, as evidenced by their various argumentative strategies. The antireligious harked "back" to what they perceived as a radical tradition, reminding their opponents of their "radical heritage" and a shared history of persecution of Epicurean thinkers by religious "sects". Those writers used a strategy that can be described as a listing of names, reminiscent of a "Wanted" poster, in order to circle the problem, a new development being discussed. By calling out "former" radicals and describing their new attitude towards Jewish religion, they

99 Polland 2007: 392. 
positioned themselves as defenders of the classic anarchist ideals. This is not a strategy used by religious anarchists (so-called pro-traditsyonistn), who usually wrote in response to a specific author, article, or topic.

Religious anarchists generally preferred to modify the terms of the debate, e.g., by distinguishing between "religion" and "religiosity" or between the concept of God as a supernatural authority and a more individualistic conception. Almi addressed the problem of human suffering by expressing his deep disappointment in God for the present-day destruction of the world, thereby relating his own religious attitude to that of Job's wife, who persuaded Job to argue with God. In this respect, religious anarchists insisted on a broader range of options for conceptualizing and talking about religion - like valuing the work of the skilful storyteller Yehoash - instead of abandoning everything seemingly connected to Judaism.

In this period, therefore, rejection of religion was no longer a sine qua non of Jewish anarchism. Identifications emerged that referred to a particularistic and specifically Jewish tradition, connecting anarchist ethics to a higher meaning. Instead, domination was unacceptable to anarchism, not only with regard to religion and spirituality. In this way, the rejection of domination came to characterise anarchism more specifically than its rejection of religion, even if the antireligious stance remained widespread. This rejection of arbitrariness, petty-mindedness and cruelty was a topos shared by all participants in the debate. Antireligious authors opposed authoritarian systems that had no legitimacy apart from the force of tradition and ideologies in which the individual was subjugated. Religious anarchists put stronger emphasis on individual responsibility in religious and educational matters. High esteem for science was prevalent and equally valued, although its compatibility with ethics was disputed. Religious anarchists could also, at need, draw support from the ideas of Friedrich Schleiermacher, Ludwig Feuerbach, George Berkeley and Herbert Spencer, questioning the origins and limitations of human understanding and reason, placing science on the same epistemological level as philosophy. One could add, that religious anarchists favoured a holistic approach to science in addressing the unresolved 
question of causalities raised by A. Almi. Herman Frank shifted the area of competence and jurisdiction to philosophy, which in his view combined theology and science. Antireligious authors, on the other hand, exhibited a more liberal tendency to separate the domains of theology and science after the manner of A. L. Goldman or (even more so) Sh. Sayman. In their appeal to scientific rationality as the sole means of salvation from reactionary influence, these polemics display the ideological function of the dichotomy of religion and 'the secular' or 'politics':

Religion did not emerge alone, but in conjunction with other categories, one of them being "the secular" (non-religion). The conceptualization of "religion" and "religions" in the modern sense of private faith, or the related sense of a personal adherence to a soteriological doctrine of God, was needed for the representation of the world as a secular, neutral, factual, comprehensively quantifiable realm whose natural laws can be discovered by scientific rationality, and whose central human activity is a distinct "non-religious" sphere or domain called "politics" or "political economy". ${ }^{\text {100 }}$

Scientific rationality was to be the essence of the public sphere, the political, which was to be cleansed of religious ideas. Perhaps the antireligious acted as modernizers, which is the ideological function mentioned in Fitzgerald's introduction. In this way, they may have reproduced aspects of the ideology of "political modernity," along with its foundational distinctions between private faith and public reason, privileging the latter as the sphere of universal truth and validity. ${ }^{\text {I0I }}$

Through these debates among Jewish radicals, religious anarchists helped to sharpen and specify the concept of domination and, thereby, that of anarchism. Their opponents might argue that their mission was to dilute the radical impetus of anarchism. One may consider religious anarchists as important actors for exploring the affinities between anarchism and pious Jewish movements such as Hasidism. Of course, their opponents resisted this development, as exemplified by Sayman's furious polemic. Nevertheless,

100 Fitzgerald 2007: 6.

гог Jun 20I2: 43-46. 
the concept of anarchism that emerges from these dialogues is broad enough that it may be represented even by religious actors, forcing historical research to re-examine its own presuppositions.

\section{References}

\section{Primary sources}

Almi, A., "Ober davnen muz men dokh. . . teme: 'tsurik tsu got'. Baltshuve shtimungen bay a teyl idishe inteligents - emeser gloybn oder derniderung. Nisht kharote - nor di derhoybung fun mentshlekher khshives iz dos tsil" ['But one should pray. . . Topic: 'back to God'. Moods of spiritual return among parts of the Jewish intelligentsia True belief or submission. Not guilt - but elevation of human dignity is the goal'], FASh II.I0.40, p. 5, $7 .^{\mathrm{IO} 2}$

id., "Vi zikher iz undzer visnshaftlekher visn?" ['How certain is our scientific knowledge?'], FASh 05.I I.43, p. 2.

Almi, Eli A, Our Unfinished World: A Philosophy of Life in Discourse, Story and Fable (New York: Arco, 1947).

Ashli, Khayim, "Der radikaler gilgl fun der frumer gabete" ['The radical metamorphosis of the pious alderwoman'], FASh I3.I I.I942, p. 5, 7.

Boreysho, Menakhem, "Poezye fun gloybn, B. Lapin durkh zayne 'naye lider" ['Poetry of faith. B. Lapin and his "new songs"'], FASh I 5.03.1940, p. 5 .

Eyges, Tuvye, "Di 'frumkayt'-shtimungen fun undzere radikaln. Reaktsyonere dershaynungen fun undzer tsayt - 'tshuve' shtimungen afile in idishe radikale krayzn - Arbeter ring shuln ba'eynflust fun konservative shtremungen - iz es virklekh a 'tsuriktrit'?" ['Our radicals" "pious" moods; reactionary tendencies of our times moods of "spiritual return" (remorse, LT) even in Jewish radical circles - Workmen's Circle schools influenced by conservative currents - is this really a "turning back"?'], FASh 2I.3.4 I, p. 3.

Frank, Herman, "Vos lernt undz take di ekzakte naturvisnshaft?" ['What indeed does exact science (physics, LT) teach us?'], FASh 3.I2.1943, p. 5,7 .

го2 Subtitles of articles published in FASh could be quite lengthy; authors tended to give hypotheses and a brief abstract of their article. 
id., Anarkho-sotsyalistishe ideyen un bavegungen ba yidn. Historishe un teoretishe aynfirung [Anarchist-socialist ideas and movements among Jews. Historical and theoretical introduction], (Paris/Tel Aviv: Biblyotek fraye tribune, I95 I).

id., "Anarchism and the Jews" in Struggle for Tomorrow: Modern Political Ideologies of the Jewish People, ed. Basil J. Vlavianos and Feliks Gross (New York: Arts, Inc., I954), 276-90.

Gelberg, A., "Traditsyes, velkhe? Problemen fun idish-veltlekher shul." ['Traditions, but which? Issues of the Jewish secular school'], FASh 23.6.39, p. 3, 7 .

Goldberg, N., "Sotsyale lere vos makht fun 'mentshhayt' a religye." ['Social doctrine that turns 'humanity' into a religion'], FASh I 5.01 .43 , p. 2.

Goldman, A. L., "Vegn naturvisnshaft, religye un gedanklekher klorkeyt." ['On the natural sciences, religion and clarity of thought'], FASh $03.12 .43, \mathrm{p} \cdot 3$.

Gordin, Abba, Gruntprintsipn fun idishkayt [Principles of Jewishness], (New York: Idish Etishe Kultur Gezelshaft, I938).

id., Di froy un di bibl [Woman and Bible], (New York: Idish Etishe Kultur Gezelshaft, I939, written in Moskau I9r9).

id., Moral in idishn lebn [Morals in Jewish Life], (New York: Idish Etishe Kultur Gezelshaft, I940).

id., Communism unmasked, (New York: I. N. Hord, I940).

id., "Der moderner id un der inyen idishkayt" ['The modern Jew and the question of Jewishness'], FASh I 5.I I.I940, p. 5.

Kahan, Tsvi, "Religye un religyozitet. (An entfer tsu di vos fregn: vos iz do eygntlekh di simkhe?" ['Religion and Religiosity (An Answer to Those Who Ask: What Good Is Religion?)'], FASh 4.II.38, p. 5, 7 .

Landauer, Gustav, For Socialism, trans. David J. Parent (St. Louis: Telos Press, 1978).

Levin, Shmuel, "Di greste shafung fun mentshlekhn gayst. Tanakh iz hekhste literarishe dergraykhung un eybiker maysterverk. Vi azoy mir batsien zikh tsu undzer idisher bibl. Tsum dershaynen fun tanakh mit monumentaler iberzetsung fun farshtorbenem dikhter 
Yehoyesh." ['The greatest creation by human genius. Tanakh is the highest literary achievement and eternal masterpiece. How we relate to our Jewish bible. On the occasion of the publication of the Tanakh with a monumental translation by the deceased poet Yehoash'], FASh 28.3.4 I, p. 5,7.

Levin, Yankev, "Vegn tanakh in der idisher shul. Shtrayt-frage in di shul-krayzn un in der prese. Khumesh in di arbeter-ring shuln. Derklerung funem farfaser fun 'mayses un legendes'” ['On Tanakh in the Jewish school. Issue of debate in teachers' circles and in the press. Bible in Workmen's Circle schools. - Declaration by the author of "Stories and Legends"'], FASh, I7.0I.4I, p. 7.

Nayman, V., "Tsurik tsu got in geto?" ['Back to God [and] into the ghetto?'], FASh 29.07.38, p. 3 .

Rabinovitsh, Shlomo, "Vos iz do eygntlekh di simkhe? (A religiezer renesans af der idisher gas?)" ['What Good Is Religion? (A Religious Renaissance among Jews?)'], FASh I6.09.3 8, p. 5.

Sayman, Shlomo, "Naymodishe frumkeyt on der alter pashtes un tmimes" ['Fashionable piety without [its] former simplicity and modesty'], FASh I3.I I.I942, p. 3.

Tenenboym, Shea, "H. Royzenblats nay lider-bukh af tanakh-motivn" ['H. Rozenblats new volume of poems on biblical motifs'], FASh 8.I2.44, p. 5 .

\section{Literature}

Avrich, Paul, The Russian Anarchists, (Studies of the Russian Institute, Columbia Univ., Princeton, N.J.: Princeton Univ. Press, I967).

id., The Anarchists in the Russian Revolution, (New York: Cornell Univ. Press, I973).

id., Anarchist Portraits, (Princeton, N.J: Princeton Univ. Press, I988).

Bakunin, Mikhail A., Bakunin on Anarchism, (New York: A.A. Knopf, I972) (Montréal: Black Rose Books, I980).

Biagini, Furio, Nati altrove: il movimento anarchico ebraico tra Mosca e New York [Born Elsewhere: The Jewish Anarchist Movement Between Moscow and New York], (Pisa: Biblioteca Franco Serantini, I998). 
Brubaker, Rogers, Ethnicity Without Groups, (Cambridge, Mass.: Harvard Univ. Press, 2004).

Buber, Martin, Between Man and Man, trans. Ronald Gregor-Smith, (London: Routledge, 2002).

Cohen, Joseph J., Di yidish-anarkhistishe bavegung in Amerike: Historisher iberblik un perzenlekhe iberlebungen [The YiddishAnarchist Movement in America: Historical Survey and Personal Experiences] (Philadelphia: Radical Library, Branch 273 Arbeter Ring, I945).

Cohn, Jesse, "Messianic Troublemakers: The Past and Present Jewish Anarchism," Zeek, April ([online: http://www.zeek.net/politics_0504. shtml, accessed Feb I2 20I6], 2005).

Colson, Daniel, “Belief, Anarchism and Modernity," Anarchist Studies I 5.I (2007), pp. 55-65.

Dubnow, Simon, Die neueste Geschichte des jüdischen Volkes: I789I 9I4 ['The recent history of the Jewish people: I789-I9I4'], 3 vols (Berlin: Jüdischer Verlag, I922).

Eisenberg, Evan, "The Mountain and the Tower: Wilderness and City in the Symbols of Babylon and Israel," in Torah of the Earth: Exploring 4,00o Years of Ecology in Jewish Thought, Volume I, ed. by Arthur Waskow (Woodstock, VT: Jewish Lights Publications, 2000), pp. I 8-54.

Ferguson, Kathy. "Anarchist Counterpublics,” New Political Science, 32.2, (June 20IO), pp. I93-2I4.

Fishman, William J., East End Jewish Radicals I875-I9I4, (Nottingham: Five Leaves, 2004).

Fitzgerald, Timothy, ed., Religion and the Secular. Historical and Colonial Formations, (London, Oakville: Equinox, 2007).

Gdalia, P., Kemfer un denker [Fighters and Thinkers], (Tel Aviv: Farlag Ashuakh, 1963).

Goncharok, Moshe, Пепел Наших Костров: Очерки Истории Еврейского Анархистского Движения [Ashes From Our Fires: Historical Survey of the Yiddish Anarchist Movement], (Jerusalem: Problemen, 2002). 
id., Tsu der geshikhte fun der anarkhistisher prese af yidish [On the History of the Anarchist Press in Yiddish], (Jerusalem: Problemen, I997).

Horkheimer, Max,; Adorno, Theodor W., Dialektik der Aufklärung: Philosophische Fragmente, (Frankfurt/M.: Fischer, I969).

id., Dialectic of Enlightenment, (New York: Continuum Pub. Co., I947/I969).

Howe, Irving, World of Our Fathers: The Journey of the East European Jews to America and the Life They Found and Made, (New York: Simon \& Schuster, I976).

Jun, Nathan, Anarchism and political modernity, (New York: Continuum, 20I2).

Marx, Karl, “Zur Judenfrage,” in Marx-Engels-Werke (MEW), vol. I, (Berlin/GDR: Dietz, I843/I976), pp. 347-377.

id., "On the Jewish Question" in Collected Works, vol. 3, (London: Lawrence \& Wishart, I843/I975), pp. I46-74.

id., "Zur Kritik der Hegelschen Rechtsphilosophie. Einleitung” ['Critique of Hegel's Philosophy of Right: Introduction'], Marx-Engels-Werke, Vol. I, (Berlin/GDR: Dietz, I844/I976), pp. 378-39I.

id., Das Kapital. Kritik der politischen Ökonomie, Vorwort zur ersten Auflage, Marx-Engels-Werke, Vol. 23, (Berlin: Dietz, I867/I998).

id., Capital, A Critique of Political Economy. Vol. I, Preface to the First German Edition, ([online: https://www.marxists.org/archive/ marx/works/I 867-cr/pr.htm, accessed Feb I2 2016], I867).

Michels, Tony, A Fire in Their Hearts: Yiddish Socialists in New York, (Cambridge, Mass.: Harvard Univ. Press, 2005).

Most, Johann, Die Gottespest: Anti-Sillabus, (New York: Ed. AV., I 883 ).

id., The God Pestilence, (New York: Published by Freiheit Pub. Association, I883/I900).

Nedava, Joseph, “Abba Gordin: A Portrait of a Jewish Anarchist," Soviet Jewish Affairs / East European Jewish Affairs, 2 (1974), pp. 73-79. 
Niger, Shmuel; Shatski, Yankev; and Shtarkman, Moshe, eds., Leksikon fun der nayer yidisher literatur [Lexicon of the New Yiddish Literature; LNYL], 6 vols (New York: Alveltlekher Yidisher Kultur Kongres, I956).

Polland, Annie, “'May a Freethinker Help a Pious Man?': The Shared World of the 'Religious' and the 'Secular' Among Eastern Jewish Immigrants to America," American Jewish History, 93.4 (2007), pp. $375-407$.

Rosenberg, Karen, "The Cult of Self-Sacrifice in Yiddish Anarchism and Saul Yanovsky's 'The First Years of Jewish Libertarian Socialism" "in Yiddish and the Left: Papers of the Third Mendel Friedman International Conference on Yiddish, eds. Gennady Estraikh and Mikhail Krutikov (Oxford: Legenda, 200I), pp. I78-94.

Singer, Israel Y., Fun a velt vos iz nishto mer [Of a World That Is No More], (New York: Farlag Matones, I946).

Tsherikover, Elye, ed., Geshikhte fun der yidisher arbeter-bavegung in di fareynikte shtatn [History of the Jewish Labor Movement in the United States], vol. 2 (New York: Yivo Institute for Jewish Research, I945).

Traverso, Enzo, The Marxists and the Jewish Question: The History of a Debate, I843-1943, (Atlantic Highlands, NJ: Humanities Press, I994).

Tremlett, Paul-François, "On the Formation and Function of the Category 'Religion' in Anarchist Writing," Culture and Religion $5 \cdot 3$ (2004), pp. 367-38I.

Türk, Lilian, Religiöser Nonkonformismus und Radikale Yidishkayt. Abba Gordin (I 887-I 964) und die Prozesse der Gemeinschaftsbildung in der jiddisch-anarchistischen Wochenschrift Fraye Arbeter Shtime I937-I945 [Religious Non-Conformism and Radical Yidishkayt. Abba Gordin (I887-I964) and Group-Building Processes in the Yiddish-Anarchist Weekly Fraye Arbeter Shtime 1937-I964 (in German)], Ph.D diss., Halle-Wittenberg University, 2014 (publ. online: urn:nbn:de:gbv:3:4-I6253).

Weber, Max, Wirtschaft und Gesellschaft, Grundriss der verstehenden Soziologie, (Neu Isenburg: Melzer, 2005). 
id., Economy and Society: An Outline of Interpretive Sociology (Berkeley: University of California Press, I979).

Weinreich, Max, "On the Impact of Religion on Language in Ashkenazic Jewry" in Readings in the Sociology of Language, ed. by Joshua A. Fishman (The Hague, Paris, New York: De Gruyter, I968), pp. 382-4I3.

Zimmer, Kenyon, Immigrants Against the State. Yiddish and Italian Anarchism in America (The Working Class in American History Series; Urbana, Chicago, Springfield: Univ. of Illinois Press, 201 5 ). 